\title{
Seed Priming Technique as Innovation to Improve Germination in Onion (Allium cepa L.)
}

\author{
Matthew Aluko \\ Department of Crop, Horticulture and Landscape Design, Ekiti State University, Ado-Ekiti, Nigeria. \\ E-mail:matthew.aluko@eksu.edu.ng
}

Olufemi J. Ayodele

Department of Soil Resources and Environmental Management, Ekiti State University, Ado-Ekiti, Nigeria.E-mail: olufemi.ayodele@eksu.edu.ng

\author{
Ayodeji E. Salami \\ Department of Crop, Horticulture and Landscape Design, Ekiti State University, Ado-Ekiti, Nigeria. \\ E-mail:ayodeji.salami@eksu.edu.ng
}

Oluwabukola E.Olaleye

Department of Crop, Horticulture and Landscape Design, Ekiti State University, Ado-Ekiti, Nigeria E-mail: oluwabukolmiolaleye.e@gmail.com

Received: 25 Nov. 2019 / Accepted 05 Jan. 2020 / Publication date: 15 Jan. 2020

\begin{abstract}
The onion production in south-west agro-ecological zone of Nigeria can be realized through the adoption of techniques that ensure rapid and uniform seed germination and seedling emergence. The effects of priming were assessed on onion seed germination and seedling emergence in a pot study at the Teaching and Research Farm of Ekiti State University, Ado-Ekiti, Nigeria. The priming media were: ascorbic acid (AA), sodium chloride $(\mathrm{NaCl})$ and moringa leaf extract (MLE) at two concentrations (12.5 and 25\%) and water. Onion seeds (Red Creole variety) were soaked in the media for 6 and 12 hours, removed, washed; air dried for 0, 24 and 48 hours; and sowed into pots. Data were collected on emergence percentage (EP), mean emergence time (MET), emergence index (EI) and time to $50 \%$ emergence $\left(\mathrm{T}_{50}\right)$ for 15 days after sowing (DAS). The results show that the priming media, concentrations and soaking durations differed significantly from the control $(\mathrm{P}<0.05)$ while the MET, $\mathrm{EI}$ and $\mathrm{T}_{50}$ did not differ. AA at 12.5 and $25 \%$ gave the highest EP (72.00 and $73.67 \%$ respectively) while seeds soaked in MLE for six hours gave the highest EP at 6 DAS (3.67\%). Seed re-drying resulted in lower EP except in seeds soaked in $\mathrm{NaCl}$. AA and MLE which gave better seeds emergence can be readily adopted as effective and environment-friendly alternatives to popular priming strategies used to enhance onion seed germination.
\end{abstract}

Keywords: Onion, priming, ascorbic acid, moringa leaf extract, sodium chloride, germination, emergence

\section{Introduction}

Onion (Allium cepa L.) is grown mainly as an annual for the bulb formed from the flattened bases of hollow and glaucous leaves and only carried forward into the second year for seeds (Addai and Anning, 2015). Onion is an indispensable part of many food preparations and consumed regularly in small quantities. Apart from the nutritive value as a source of vitamins and minerals, it has numerous benefits due to the antiseptic and therapeutic qualities that aid in the cure of pulmonary diseases in folk medicine and lowering of blood sugar and blood pressure (Tadimalla, 2017). Bulb onion is widely grown in sub-humid to semi-arid climate in the Guinea and Sudan savannah zones of Nigeria (FFD, 2011) with output of 1.69 million metric tons from 0.26 million hectares (ha) in 2009 (FMARD, 2010).

The quality of onion seeds is one of the greatest challenges faced by onion farmers. The environmental conditions during growth and seed development on mother plants, location of seeds on the plant, time and technology of harvesting, processing and storage conditions and the type of seed treatment before sowing affect seed quality (Dorna et al., 2013). Currently, some of these variables are difficult to regulate in the Nigerian seed industry. Besides, onion seeds have low quality which is responsible for slow and asynchronous germination and abnormal seedlings especially under interacting 
abiotic stress conditions in the field (Borowski and Michalek, 2006). Thus, sowing onion seeds to obtain rapid and uniform seedling emergence, good vegetative growth, and high bulb yield would require seed pre-treatment before sowing.

Seed-priming has been adopted as one of the techniques for producing good quality seedlings. Seed-priming entails regulation of the germination process by managing the moisture content and temperature of the seeds and has become one of the physiological methods which improve seed performance and provide faster and synchronized germination (Saranya et al., 2017). Seed-priming increases seed germination rates, seedling emergence and establishment and, in some cases, stimulate vegetative growth and increases crop yield (Caseiro et al., 2004, Selvarani and Umarani, 2011; Dorna et al., 2013). Different seed-priming techniques have been developed for onion and applied under different cropping systems and the outcomes of the treatments varied. Priming increased seed vigour (Selvarani and Umarani, 2011; Matthews and Powell, 2011), influence speed of emergence (Adebisi, et al., 2011) and synchronized germination (Farooq et al., 2009). Seedlings that developed from primed seeds were highly competitive against weeds and tolerant to environmental stresses factors (Hosseein et al., 2011). Notably, hydro-priming (soaking seeds in water) (Hosseein and Karsa, 2011), halopriming (soaking seeds in organic salt solution) (Abbasdokht, 2011), hormonal priming (soaking seeds in plant growth regulators), osmo-priming (soaking seeds in solution of low water potential, usually polyethylene glycol) (Caseiro et al., 2004, Dorna et al., 2013) and matrix-priming (solid matrix priming) (Nawaz et al., 2013) are some of the widely used techniques.

Primed seeds are usually re-dried to initial safe seed moisture content to preserve quality caused by seed deterioration (Huang et al., 2002, Ratikanta, 2011, Di Girolamo and Barbanti, 2012). However, the speed and the drying temperature are important and there are contrasting reports on their effects on seed quality. Armstrong and McDonald (1992) and Parera and Cantliffe (1992) reported that rapid redrying caused mechanical damage to seeds while Huang et al. (2002) reported that the physiological gain through seed priming was not lost after re-drying. Caseiro et al. (2004) stated that seed moisture content before and after priming is an important factor to be considered in order to select the best onion seed-priming procedure. By the use of hydro and osmo-priming, Dorna et al. (2013) observed that after re-drying of primed onion seeds at $20^{\circ} \mathrm{C}$ for 48 hours, onion seeds stored for 6 months and the drying temperature had no significant effect on quality.

Moringa oleifera leaf extract is rich in zeatin, amino acid, ascorbate, zeatin, minerals, and many other compounds (Hussain et al., 2013) and has been used as priming medium on plant seeds (Nouman et al., 2012). More information is required on aspects of priming method, effects of the chemistry of priming solvents and drying temperature on seed qualities in order to develop sustainable cultural practices for onion production. The aim of this study was to prime onion seeds using water extract of Moringaoleifera (phyto-priming) and compare the results with water-, halo- and hormone-priming techniques and optimize the process to improve uniformity, speed and percentage emergence in onion seeds.

\section{Materials and Methods}

The experiment was conducted in the screen house of the Department of Crop, Horticulture and Landscape Design, Faculty of Agricultural Sciences, Ekiti State University, Ado-Ekiti, Nigeria $\left(5^{\circ} 45^{\prime}\right.$ $\mathrm{N}$ and $8^{\circ} 15^{\prime} \mathrm{E}$ ). Viable seeds of Red Creole variety, the most widely-cultivated onion with great commercial value to the farmers, were collected from National Horticultural Research Institute, Bagauda, Kano State. The surface layer $(0-15 \mathrm{~cm})$ soil samples were randomly collected from a plot at the Teaching and Research Farm, bulked and sieved $(<2 \mathrm{~mm}) .2 \mathrm{~kg}$ soils were weighed into flat plastic containers $\left(10.04 \mathrm{~m}^{2}\right)$ arranged in completely randomized design with three replicates and watered to keep the soils moist. The following were the treatments:

1. Hydro-priming: onion seeds soaked in two test tubes containing $10 \mathrm{ml}$ distilled water for 6 and 12 h.

2. Halo-priming: onion seeds soaked in 12.5 and $25 \%$ solution of sodium chloride $(\mathrm{NaCl})$ for 6 and $12 \mathrm{~h}$.

3. Hormonal-priming: onion seeds soaked in 12.5 and $25 \%$ solution of ascorbic acid for 6 and $12 \mathrm{~h}$. 
4. Phyto-priming: onion seeds soaked in 12.5 and $25 \%$ of moringa leaf extract (MLE). The extract was prepared by blending the fresh and washed leaves of Moringaoleiferacollected from the Teaching and Research Farm in distilled water.

5. Unprimed seeds as control.

The primed seeds were removed, rinsed with distilled water and re-dried for 0,24 , and 48 hours. The primed and unprimed were sowed in the respective treatments at 20 seeds pot $^{-1}$ and the soils were kept moist by watering daily.

The number of emerged seedlings was counted from the first day of emergence (6 days after sowing, DAS) to 15 DAS. The data were used to calculate some measures based on Wu et al. (2017) as follows:

a) Emergence percentage $(E P)=\frac{n}{N} \times 100$

where $\mathrm{n}=$ number of germinated seeds

b) Mean Emergence Time (MET) $=\sum \frac{\mathrm{nt}}{\mathrm{N}}$

$\mathrm{N}=$ total number of seeds sowed

where $\mathrm{n}$ is the number of germinated seeds in $\mathrm{t}$ days.

c) Emergence index $(\mathrm{EI})=\sum\left(\frac{E t}{D t}\right)$

where Et is the number of emergence seeds in $\mathrm{t}$ days; $\mathrm{Dt}$ is the number of corresponding germination days.

d) The time until 50\% germination ( $\left.\mathrm{T}_{50}\right)$ using the formula developed by Farooq et al. (2005)

$$
\mathrm{T}_{50}=\mathrm{tj}+\left(\frac{\mathrm{N}}{2}-\mathrm{ni}\right)(\mathrm{tj}-\mathrm{ti}) / \mathrm{nj}-\mathrm{ni}
$$

where $\mathrm{N}=$ final number of germinated seeds

$\mathrm{ni}$ and $\mathrm{nj}$ are cumulative numbers of germinated seeds at adjacent counts at times ti and tj when $\mathrm{ni}<\mathrm{N} / 2<\mathrm{nj}$

All the data collected were subjected to analysis of variance and regression. The differences between treatment means were separated using Duncan's Multiple Range Test at 5\% level of significance.

\section{Results}

\section{The effect of priming media on onion seeding emergence}

The seedlings emerged at $6 \mathrm{DAS}$ in MLE, $\mathrm{NaCl}$ and ascorbic acid (AA) treatments with the highest percentage in MLE not significantly different $(\mathrm{P}<0.05)$ (Table 1). The onion seeds in the control treatment, soaked in water, $25 \%$ ascorbic acid (AA) concentration and soaked for $12 \mathrm{~h}$ in AA and $\mathrm{NaCl}$ had no emergence at 6 DAS whereas $6 \mathrm{~h}$ soaking in AA and $\mathrm{NaCl}, 6$ and $12 \mathrm{~h}$ soaking in MLE induced early emergence (Table 2 and 3). All the treatments had emerged seedlings at 7 DAS with the control giving the highest percentage but the difference among the treatments was not significant. The least values in water at 8 and $9 \mathrm{DAS}$ were similar to $\mathrm{NaCl}$ and the control which did not differ from the highest emergence in AA and MLE. The highest seedling emergence at 8 and 9 DAS in 25\% AA was not significantly different $(\mathrm{P}<0.05)$ from $12.5 \% \mathrm{AA}$ and the two concentrations of MLE and $\mathrm{NaCl}$. The performance of the priming media were the same between 10 and 15 DAS with the highest percentage in AA which was not significantly different from MLE and at each time, MLE gave values similar to $\mathrm{NaCl}$. But $25 \%$ concentration MLE at 14 and 15 DAS was significantly different from both concentrations of $\mathrm{AA}$ and $12.5 \%$ MLE. The percentage emergence in water and control was not significantly different till the 14 DAS. At the final day of data collection (15 DAS) all priming media were significantly different $(\mathrm{P}<0.05)$ from the control. The best priming media in terms of emergence performance at 15 DAS were AA and MLE. The MET was highest in the control treatment and not different significantly $(\mathrm{P}<0.05)$ from $\mathrm{NaCl}$, water and $12.5 \%$ MLE. The priming media were not significantly different in EI but $\mathrm{T}_{50}$ in water was significantly different from other priming media. The EI was highest in $12.5 \% \mathrm{AA}$ and least in water but the values did not differ significantly while $\mathrm{T}_{50}$ in water was higher than the other treatments 
Table 1: The effect of priming media on onion seeding emergence (\%).

\begin{tabular}{|c|c|c|c|c|c|c|c|c|c|c|c|c|c|}
\hline \multirow{2}{*}{ Media } & \multicolumn{10}{|c|}{ Day after sowing } & \multirow{2}{*}{ MET } & \multirow{2}{*}{ EI } & \multirow{2}{*}{$\mathbf{T}_{\mathbf{5 0}}$} \\
\hline & 6 & 7 & 8 & 9 & 10 & 11 & 12 & 13 & 14 & 15 & & & \\
\hline Ascorbic acid & $0.83 a$ & $9.17 \mathrm{a}$ & $25.33 a$ & $39.83 a$ & $54.46 a$ & $64.79 \mathrm{a}$ & $70.88 \mathrm{a}$ & $72.58 \mathrm{a}$ & $72.83 a$ & $72.83 a$ & $6.33 b$ & 5.58 & $9.07 \mathrm{~b}$ \\
\hline MLE & $2.42 \mathrm{a}$ & $9.58 \mathrm{a}$ & $22.00 \mathrm{a}$ & $36.42 \mathrm{a}$ & $49.04 \mathrm{ab}$ & $61.00 \mathrm{ab}$ & $68.58 \mathrm{ab}$ & $69.71 \mathrm{ab}$ & $70.13 \mathrm{ab}$ & $70.13 \mathrm{ab}$ & $6.58 b$ & 5.20 & $8.98 b$ \\
\hline $\mathrm{NaCl}$ & $1.25 \mathrm{a}$ & $7.04 \mathrm{a}$ & $16.42 \mathrm{ab}$ & $28.54 \mathrm{ab}$ & $40.33 b c$ & $51.33 \mathrm{bc}$ & $60.33 b$ & $64.79 b c$ & $66.50 \mathrm{bc}$ & $66.92 \mathrm{c}$ & $7.42 \mathrm{ab}$ & 5.41 & $9.32 \mathrm{~b}$ \\
\hline Water & $0.00 \mathrm{a}$ & $1.42 \mathrm{a}$ & $5.00 \mathrm{~b}$ & $16.08 \mathrm{~b}$ & $25.58 \mathrm{~d}$ & $37.00 \mathrm{~d}$ & $49.17 \mathrm{c}$ & $58.83 \mathrm{c}$ & $64.42 \mathrm{c}$ & $67.50 \mathrm{bc}$ & $7.33 \mathrm{ab}$ & 4.65 & $10.30 \mathrm{a}$ \\
\hline Control & $0.00 \mathrm{a}$ & $11.50 \mathrm{a}$ & $20.00 \mathrm{ab}$ & $25.00 \mathrm{ab}$ & $33.50 \mathrm{~cd}$ & $41.50 \mathrm{~cd}$ & $51.50 \mathrm{c}$ & $58.50 \mathrm{c}$ & $60.00 \mathrm{~d}$ & $60.00 \mathrm{~d}$ & $8.00 \mathrm{a}$ & 5.60 & $9.50 \mathrm{~b}$ \\
\hline
\end{tabular}

Mean emergence time (MET), Emergence index (EI), Time of 50\% emergence (T50), Moringa leaf extract (MLE), Sodium chloride (NaCl). Mean with same letter(s) are not significantly different at $5 \%$ probability using Duncan's multiple range test.

Table 2: Interaction between the priming media and concentration on onion seeding emergence (\%).

\begin{tabular}{|c|c|c|c|c|c|c|c|c|c|c|c|c|c|c|}
\hline \multirow{2}{*}{ Media } & \multirow{2}{*}{$\begin{array}{c}\text { Concentration } \\
(\%)\end{array}$} & \multicolumn{10}{|c|}{ Day after sowing } & \multirow{2}{*}{ MET } & \multirow{2}{*}{ EI } & \multirow{2}{*}{$\mathbf{T}_{50}$} \\
\hline & & 6 & 7 & 8 & 9 & 10 & 11 & 12 & 13 & 14 & 15 & & & \\
\hline \multirow{2}{*}{$\mathbf{A A}$} & 12.5 & $1.67 \mathrm{a}$ & $7.50 \mathrm{a}$ & $24.17 \mathrm{a}$ & $37.67 \mathrm{ab}$ & $52.50 \mathrm{ab}$ & $64.25 \mathrm{a}$ & $71.17 \mathrm{a}$ & $72.00 \mathrm{ab}$ & $72.00 \mathrm{ab}$ & $72.00 \mathrm{a}$ & $6.33 b c$ & $5.70 \mathrm{a}$ & $9.08 \mathrm{~b}$ \\
\hline & 25 & $0.00 \mathrm{a}$ & $10.83 a$ & $26.50 \mathrm{a}$ & $42.00 \mathrm{a}$ & $56.42 \mathrm{a}$ & $65.33 \mathrm{a}$ & $70.58 \mathrm{a}$ & $73.17 \mathrm{a}$ & $73.67 \mathrm{a}$ & $73.67 \mathrm{a}$ & $6.33 \mathrm{bc}$ & $5.45 \mathrm{a}$ & $9.05 b$ \\
\hline \multirow{2}{*}{ MLE } & 12.5 & $3.42 \mathrm{a}$ & $11.08 \mathrm{a}$ & $24.50 \mathrm{a}$ & $39.50 \mathrm{ab}$ & $52.50 \mathrm{ab}$ & $63.58 \mathrm{a}$ & $71.67 \mathrm{a}$ & $71.67 \mathrm{a}$ & $71.67 \mathrm{a}$ & $71.67 \mathrm{a}$ & $7.17 \mathrm{abc}$ & $5.27 \mathrm{a}$ & $9.10 \mathrm{~b}$ \\
\hline & 25 & $1.42 \mathrm{a}$ & $8.08 \mathrm{a}$ & $19.50 \mathrm{ab}$ & $33.33 \mathrm{ab}$ & $45.58 \mathrm{abc}$ & $58.42 \mathrm{ab}$ & $65.50 \mathrm{ab}$ & $67.75 \mathrm{abc}$ & $68.58 b c$ & $68.58 b$ & $6.00 \mathrm{c}$ & $5.13 \mathrm{a}$ & $8.85 b$ \\
\hline \multirow{2}{*}{$\mathrm{NaCl}$} & 12.5 & $1.67 \mathrm{a}$ & $5.50 \mathrm{a}$ & $15.83 \mathrm{ab}$ & $28.25 \mathrm{abc}$ & $40.67 \mathrm{bc}$ & $54.33 \mathrm{ab}$ & $61.67 b$ & $65.58 b c$ & $67.50 \mathrm{~cd}$ & $68.33 b$ & $7.50 \mathrm{ab}$ & $5.45 a$ & $9.33 b$ \\
\hline & 25 & $0.83 a$ & $8.58 \mathrm{a}$ & $17.25 \mathrm{ab}$ & $28.83 \mathrm{abc}$ & $40.00 \mathrm{bc}$ & $48.33 b c$ & $59.00 \mathrm{bc}$ & $64.00 \mathrm{~cd}$ & $65.50 \mathrm{~cd}$ & $65.50 \mathrm{c}$ & 7.33abc & $5.37 \mathrm{a}$ & $9.30 \mathrm{~b}$ \\
\hline Water & & $0.00 \mathrm{a}$ & $1.42 \mathrm{a}$ & $5.00 \mathrm{~b}$ & $16.08 \mathrm{c}$ & $25.58 \mathrm{~d}$ & $37.00 \mathrm{c}$ & $49.17 d$ & $58.83 \mathrm{~d}$ & $64.42 \mathrm{~d}$ & $67.50 \mathrm{bc}$ & 7.33abc & $4.65 a$ & $10.30 \mathrm{a}$ \\
\hline Control & & $0.00 \mathrm{a}$ & $11.50 \mathrm{a}$ & $20.00 \mathrm{ab}$ & $25.00 \mathrm{bc}$ & $33.50 \mathrm{~cd}$ & $41.50 \mathrm{c}$ & $51.50 \mathrm{~cd}$ & $58.50 \mathrm{~d}$ & $60.00 \mathrm{e}$ & $60.00 \mathrm{~d}$ & $8.00 \mathrm{a}$ & $5.60 \mathrm{a}$ & $9.50 \mathrm{~b}$ \\
\hline
\end{tabular}

Mean emergence time (MET), Emergence index (EI), Time of 50\% emergence ( $\mathrm{T}_{50}$ ). Mean with same letter(s) on the same column are not significantly different at $5 \%$ probability using Duncan's multiple range test. 


\section{The effect of concentration on onion seeding emergence.}

The effects of concentration of the priming media on seedling emergence in onion over time are shown in Fig. 1. The seedlings emerged at 6 DAS from only the 12.5 and $25 \%$ concentrations with similar percentages while the $0 \%$ and water showed no emergence (Table 4 ). Over the 7-15 DAS period, the highest percentage emergence at $12.5 \%$ concentration was not significantly different from $25 \%$ but both were significantly different from the $0 \%$. At the final day of observation (15 DAS), the highest emergence at $12.5 \%$ was not significantly different from $25 \%$ concentration. The MET was highest in the $25 \%$ and did not differ significantly from $12.5 \%$ concentration. The $12.5 \%$ concentration gave the highest EI which was not significantly different from $25.0 \%$ concentration while the control gave the highest $\mathrm{T}_{50}$ that was significantly different from the two concentrations at $\mathrm{P}<0.05$.

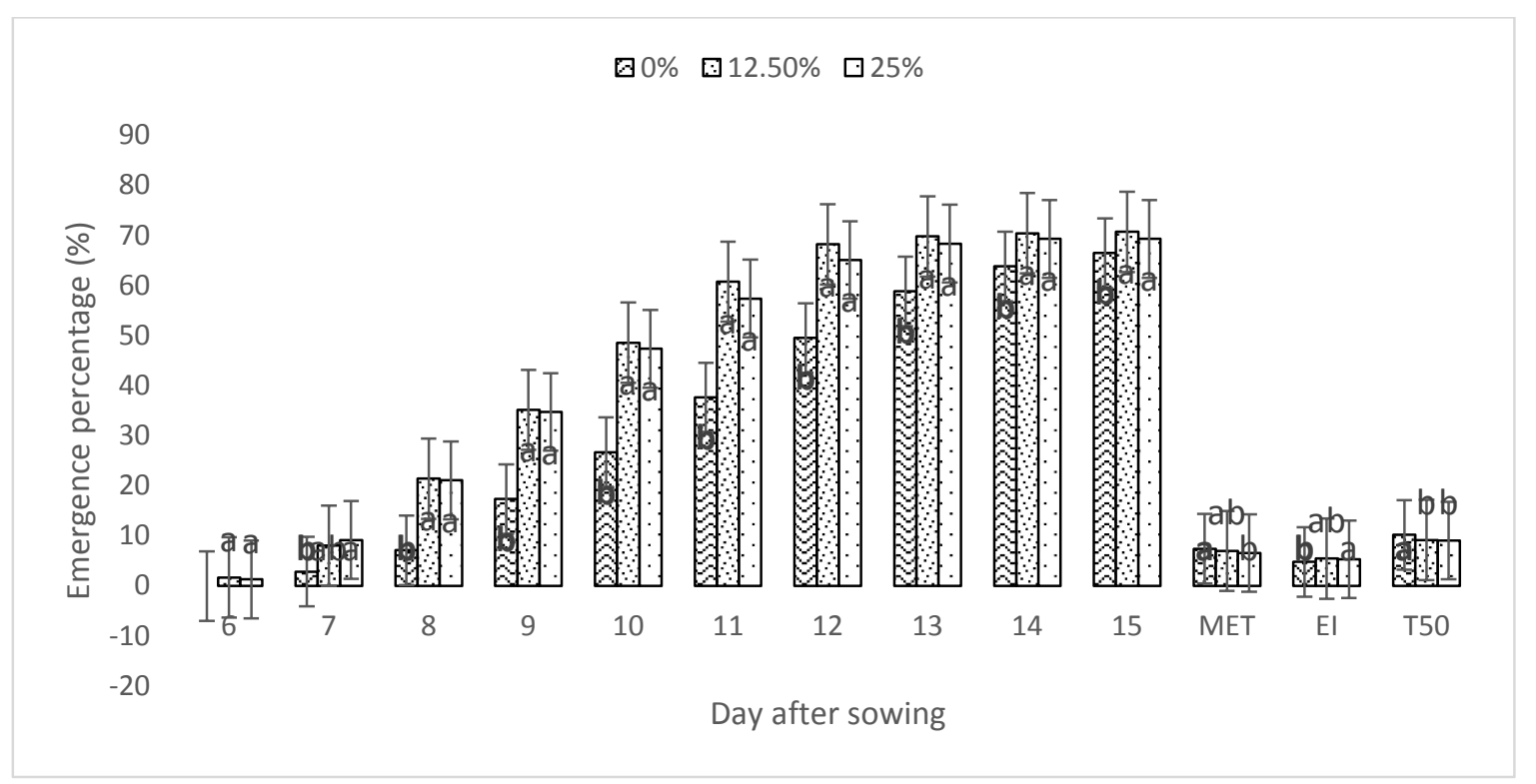

Fig. 1: The effect of concentration on onion seeding emergence.

Mean emergence time (MET), Emergence index (EI), Time of 50\% emergence $\left(\mathrm{T}_{50}\right)$. Mean with same letter(s) are not significantly different at 5\% probability using Duncan's multiple range test.

\section{The effect of soaking time on onion seeding emergence.}

Fig. 2 shows the mean effects of soaking time in the priming media on the percentage seedling emergence in onion. At 6 DAS, no seedling had emerged in the control while the emergence increased with soaking time but the difference was not significant $(\mathrm{P}<0.05)$. At $7 \mathrm{DAS}$, the control had the highest emergence which was not significantly different from emergence that decreased with soaking time. Soaking in $12.5 \%$ concentration for $6 \mathrm{~h}$ gave higher percentage emergence than $25 \%$ in $6 \mathrm{~h}$ (Table 3 ). At 7 DAS, the interaction was not significant and the highest values obtained in the control, 12.5 and $25 \%$ concentration for $6 \mathrm{~h}$ were similar. The trend at 8-10 DAS showed highest emergence at soaking for $6 \mathrm{~h}$ which did not differ from the control $(0 \mathrm{~h})$ and soaking for $12 \mathrm{hrs}$. The performance was similar at 11-15 DAS but with highest emergence in soaking for $6 \mathrm{~h}$ not significantly different $(\mathrm{P}<0.05)$ from soaking for $12 \mathrm{~h}$. The highest emergence was from soaking seeds in $12.5 \%$ concentration of priming media which differed significantly from $0 \%$ for $12 \mathrm{~h}$ at $8-9$ DAS, control and $0 \%$ at $10-14$ DAS. At the final day of observation (15 DAS), $6 \mathrm{~h}$ soaking gave the highest emergence that was not significantly different from $12 \mathrm{~h}$ soaking. At 7-15 DAS, $6 \mathrm{~h}$ soaking in AA gave the highest emergence which was significantly different from water and the control treatments while the difference from $12 \mathrm{~h}$ soaking in $\mathrm{NaCl}$ was significant at 10-15 DAS. Soaking the seeds in AA for 6 and $12 \mathrm{~h}$ and MLE for $12 \mathrm{~h}$ at 15 DAS were not significantly different at $\mathrm{P}<0.05$. The control $(0 \mathrm{~h})$ gave the highest MET, EI and $\mathrm{T}_{50}$ which did not differ significantly from the soaking times. The $6 \mathrm{~h}$ soaking in AA and $12 \mathrm{hrs}$ soaking in MLE gave the least MET which only differed significantly from the control; EI was not different among AA, MLE, $\mathrm{NaCl}$, soaking in water for $6 \mathrm{~h}$ and control while soaking in water for $12 \mathrm{~h}$ gave the highest $\mathrm{T}_{50}$ followed by soaking in water for $6 \mathrm{~h}$ and control. 
Table 3: Interaction between the priming media and soaking time on onion seeding emergence (\%).

\begin{tabular}{|c|c|c|c|c|c|c|c|c|c|c|c|c|c|c|}
\hline \multirow[b]{2}{*}{ Media } & \multirow{2}{*}{$\begin{array}{c}\text { Soaking } \\
\text { time } \\
\text { (Hours) }\end{array}$} & \multicolumn{10}{|c|}{ Day after sowing } & \multirow[b]{2}{*}{ MET } & \multirow[b]{2}{*}{ EI } & \multirow[b]{2}{*}{$\mathbf{T}_{\mathbf{5 0}}$} \\
\hline & & 6 & 7 & 8 & 9 & 10 & 11 & 12 & 13 & 14 & 15 & & & \\
\hline \multirow{2}{*}{$\mathbf{A A}$} & 6 & $1.67 \mathrm{a}$ & $12.50 \mathrm{a}$ & $26.75 a$ & $41.50 \mathrm{a}$ & $55.00 \mathrm{a}$ & $65.00 \mathrm{a}$ & $71.08 \mathrm{a}$ & $72.83 a$ & $73.33 a$ & $73.33 a$ & $6.17 \mathrm{~b}$ & $5.55 a$ & $9.05 \mathrm{bc}$ \\
\hline & 12 & $0.00 \mathrm{a}$ & $6.08 \mathrm{ab}$ & $23.92 \mathrm{ab}$ & $38.17 \mathrm{ab}$ & $53.92 \mathrm{a}$ & $64.58 \mathrm{a}$ & $70.67 \mathrm{ab}$ & $72.33 \mathrm{a}$ & $72.33 \mathrm{a}$ & $72.33 \mathrm{a}$ & $6.50 \mathrm{ab}$ & $5.60 \mathrm{a}$ & $9.08 \mathrm{bc}$ \\
\hline \multirow{2}{*}{ MLE } & 6 & $3.67 \mathrm{a}$ & $10.25 \mathrm{ab}$ & $23.17 \mathrm{ab}$ & $38.92 \mathrm{ab}$ & $51.33 \mathrm{a}$ & $61.92 \mathrm{a}$ & $67.67 \mathrm{abc}$ & $69.08 \mathrm{ab}$ & 69.92abc & $69.92 \mathrm{ab}$ & $6.83 a b$ & $5.50 \mathrm{a}$ & $8.95 \mathrm{c}$ \\
\hline & 12 & $1.17 \mathrm{a}$ & $8.92 \mathrm{ab}$ & $20.83 \mathrm{ab}$ & $33.92 \mathrm{ab}$ & $46.75 \mathrm{ab}$ & $60.08 \mathrm{ab}$ & $69.50 \mathrm{ab}$ & $70.33 a$ & $70.33 \mathrm{ab}$ & $70.33 \mathrm{ab}$ & $6.33 b$ & $4.90 \mathrm{ab}$ & $9.00 \mathrm{bc}$ \\
\hline \multirow{2}{*}{$\mathrm{NaCl}$} & 6 & $2.50 \mathrm{a}$ & $10.50 \mathrm{ab}$ & $21.08 \mathrm{ab}$ & $31.33 \mathrm{ab}$ & $43.92 \mathrm{abc}$ & $53.33 \mathrm{abc}$ & $61.67 \mathrm{bcd}$ & $66.42 \mathrm{abc}$ & $67.42 b c$ & $67.42 b c$ & $7.33 \mathrm{ab}$ & $5.47 \mathrm{a}$ & $9.22 \mathrm{bc}$ \\
\hline & 12 & $0.00 \mathrm{a}$ & $3.58 \mathrm{ab}$ & $11.75 \mathrm{abc}$ & $25.75 \mathrm{ab}$ & $36.75 b c$ & $49.33 b c$ & $59.00 \mathrm{cde}$ & $63.17 \mathrm{bcd}$ & $65.58 \mathrm{c}$ & $66.42 \mathrm{c}$ & $7.50 \mathrm{ab}$ & $5.35 \mathrm{a}$ & $9.42 \mathrm{bc}$ \\
\hline \multirow{2}{*}{ Water } & 6 & $0.00 \mathrm{a}$ & $2.83 \mathrm{ab}$ & $8.33 \mathrm{bc}$ & $25.00 \mathrm{~b}$ & $31.67 \mathrm{~cd}$ & $41.67 \mathrm{~cd}$ & $53.83 \mathrm{de}$ & $61.00 \mathrm{~cd}$ & $65.00 \mathrm{c}$ & $66.67 \mathrm{bc}$ & $7.67 \mathrm{ab}$ & $5.27 a$ & $9.73 b$ \\
\hline & 12 & $0.00 \mathrm{a}$ & $0.00 \mathrm{~b}$ & $1.67 \mathrm{c}$ & $9.50 \mathrm{c}$ & $19.50 \mathrm{~d}$ & $32.33 \mathrm{~d}$ & $44.50 \mathrm{f}$ & $56.67 \mathrm{~d}$ & $63.83 \mathrm{~cd}$ & $68.33 b c$ & $7.00 \mathrm{ab}$ & $4.03 \mathrm{~b}$ & $10.87 \mathrm{a}$ \\
\hline Control & $\mathbf{0}$ & $0.00 \mathrm{a}$ & $11.50 \mathrm{ab}$ & $20.00 \mathrm{ab}$ & $25.00 \mathrm{~b}$ & $33.50 \mathrm{bc}$ & $41.50 \mathrm{f}$ & $51.50 \mathrm{ef}$ & $58.50 \mathrm{~d}$ & $60.00 \mathrm{~d}$ & $60.00 \mathrm{~d}$ & $8.00 \mathrm{a}$ & $5.60 \mathrm{a}$ & $9.50 \mathrm{~b}$ \\
\hline
\end{tabular}

Mean emergence time (MET), Emergence index (EI), Time of 50\% emergence $\left(\mathrm{T}_{50}\right)$. Mean with same letter(s) on the same column are not significantly different at $5 \%$ probability

using Duncan's multiple range test.

Table 4: Interaction between the concentration and soaking time on onion seeding emergence (\%).

\begin{tabular}{|c|c|c|c|c|c|c|c|c|c|c|c|c|c|c|}
\hline \multirow{2}{*}{$\begin{array}{c}\text { Concentration } \\
(\%)\end{array}$} & \multirow{2}{*}{$\begin{array}{c}\text { Soaking } \\
\text { time } \\
\text { (Hours) }\end{array}$} & \multicolumn{10}{|c|}{ Day after sowing } & \multirow[b]{2}{*}{ MET } & \multirow{2}{*}{$\mathbf{E I}$} & \multirow[b]{2}{*}{$\mathbf{T}_{50}$} \\
\hline & & 6 & 7 & 8 & 9 & 10 & 11 & 12 & 13 & 14 & 15 & & & \\
\hline \multirow{2}{*}{12.5} & 6 & $3.00 \mathrm{a}$ & $11.44 \mathrm{a}$ & $24.17 \mathrm{a}$ & $38.22 \mathrm{a}$ & $51.11 \mathrm{a}$ & $62.33 a$ & $69.17 \mathrm{a}$ & $70.72 \mathrm{a}$ & $70.72 \mathrm{a}$ & $70.72 \mathrm{a}$ & 7.22 & $5.71 \mathrm{a}$ & $9.20 \mathrm{bc}$ \\
\hline & 12 & $0.39 \mathrm{a}$ & $4.61 \mathrm{a}$ & $18.67 \mathrm{a}$ & $32.06 \mathrm{a}$ & $46.00 \mathrm{abc}$ & $59.11 \mathrm{a}$ & $67.17 \mathrm{a}$ & $68.78 \mathrm{ab}$ & $70.06 \mathrm{a}$ & $70.61 \mathrm{a}$ & 6.78 & $5.23 \mathrm{a}$ & $9.14 \mathrm{bc}$ \\
\hline \multirow{2}{*}{25} & 6 & $2.22 a$ & $10.56 \mathrm{a}$ & $23.17 \mathrm{a}$ & $36.28 \mathrm{a}$ & $49.06 \mathrm{ab}$ & $57.83 a$ & $64.44 \mathrm{ab}$ & $68.17 \mathrm{ab}$ & $69.72 \mathrm{ab}$ & $69.72 \mathrm{a}$ & 6.33 & $5.30 \mathrm{a}$ & $8.94 \mathrm{c}$ \\
\hline & 12 & $0.39 \mathrm{a}$ & $7.78 \mathrm{a}$ & $19.00 \mathrm{a}$ & $33.17 \mathrm{a}$ & $45.61 \mathrm{abc}$ & $56.89 \mathrm{a}$ & $65.61 \mathrm{a}$ & $68.44 \mathrm{ab}$ & $68.78 \mathrm{ab}$ & $68.78 \mathrm{a}$ & 6.78 & $5.33 \mathrm{a}$ & $9.19 \mathrm{bc}$ \\
\hline \multirow{2}{*}{$\mathbf{0}$} & 6 & $0.00 \mathrm{a}$ & $2.83 a$ & $8.33 \mathrm{ab}$ & $22.67 \mathrm{ab}$ & $31.67 \mathrm{~cd}$ & $41.67 \mathrm{~b}$ & $53.83 \mathrm{bc}$ & $61.00 \mathrm{bc}$ & $65.00 \mathrm{abc}$ & $66.67 \mathrm{a}$ & 7.67 & $5.27 \mathrm{a}$ & $9.73 b$ \\
\hline & 12 & $0.00 \mathrm{a}$ & $0.00 \mathrm{a}$ & $1.67 \mathrm{~b}$ & $9.50 \mathrm{~b}$ & $19.50 \mathrm{~d}$ & $32.33 b$ & $44.50 \mathrm{c}$ & $56.67 \mathrm{c}$ & $63.83 \mathrm{bc}$ & $68.33 \mathrm{a}$ & 7.00 & $4.03 \mathrm{~b}$ & $10.87 \mathrm{a}$ \\
\hline Control & $\mathbf{0}$ & $0.00 \mathrm{a}$ & $11.50 \mathrm{a}$ & $20.00 \mathrm{a}$ & $25.00 \mathrm{ab}$ & $33.50 \mathrm{bcd}$ & $41.50 \mathrm{~b}$ & $51.50 \mathrm{c}$ & $58.50 \mathrm{c}$ & $60.00 \mathrm{c}$ & $60.00 \mathrm{~b}$ & 8.00 & $5.60 \mathrm{a}$ & $9.50 \mathrm{bc}$ \\
\hline
\end{tabular}

Mean emergence time (MET), Emergence index (EI), Time of 50\% emergence ( $\left.\mathrm{T}_{50}\right)$. Mean with same letter(s) on the same column are not significantly different at 5\% probability using Duncan's multiple range test. 


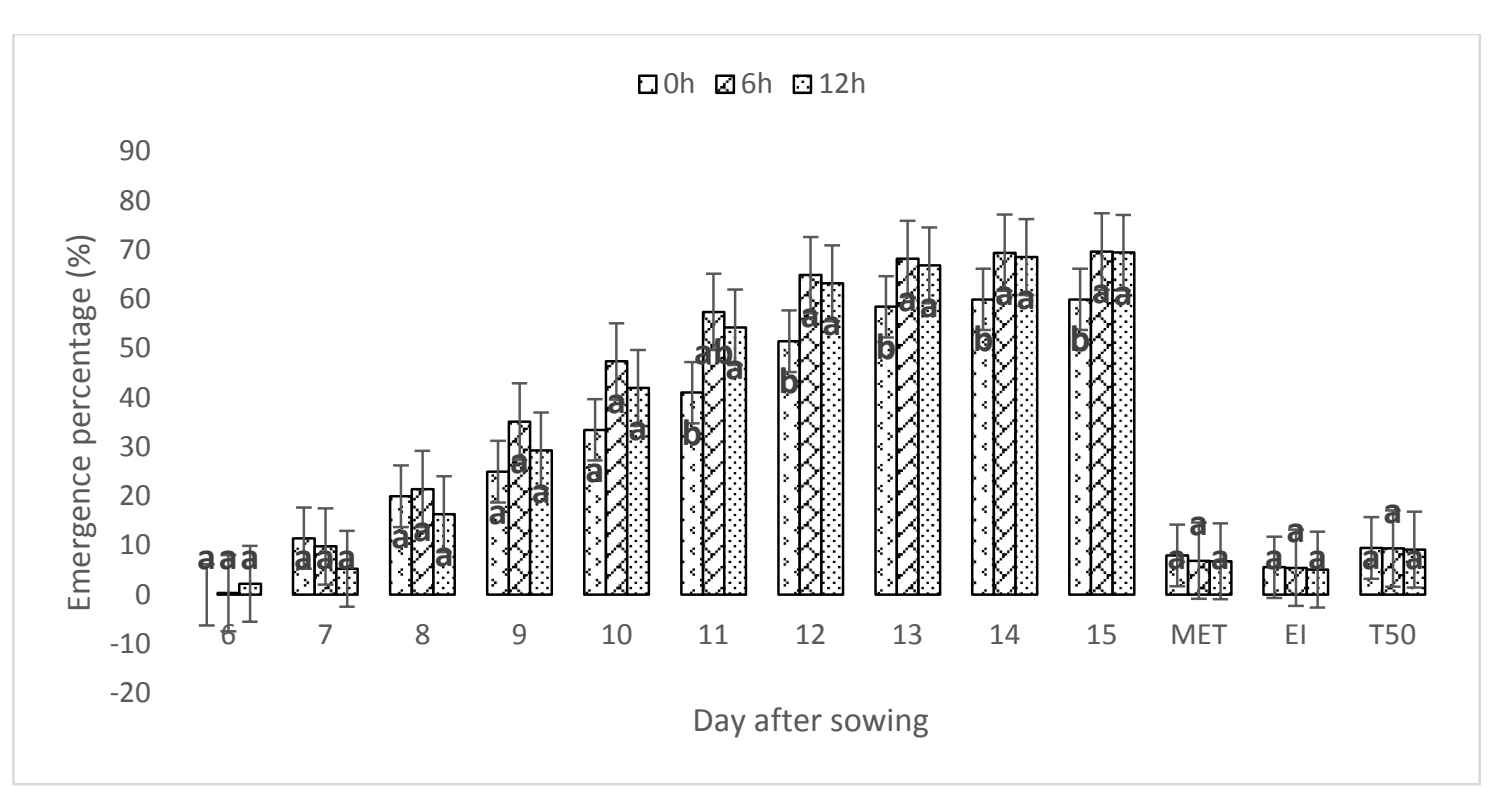

Fig. 2: The effect of soaking time on onion seeding emergence.

Mean emergence time (MET), Emergence index (EI), Time of 50\% emergence $\left(\mathrm{T}_{50}\right)$. Mean with same letter(s) are not significantly different at $5 \%$ probability using DUNCAN's multiple range test

\section{Effect of re-drying on onion seeding emergence.}

The effect of re-drying of onion seeds after soaking was showed in Table 5. Onion seeds soaked for $6 \mathrm{~h}$, washed and sowed without drying gave the highest final emergence percentage (FEP) at 70.43 $\%$ followed by soaking for $12 \mathrm{~h}$ without re-drying (70.08\%) but were not significantly different $(\mathrm{P}<0.05)$ from those onion seeds that were re-dried after soaking. All the onion seeds soaked irrespective of duration of re-drying significantly differed $(\mathrm{P}<0.05)$ from the control (non-primed onion seeds). The MET, EI and $\mathrm{T}_{50}$ were not significantly different from the control.

Table 5: Effect of re-drying on soaking durations

\begin{tabular}{cccccc}
\hline $\begin{array}{c}\text { Soaking Time } \\
\text { (Hours) }\end{array}$ & $\begin{array}{c}\text { Drying Time } \\
\text { (Hours) }\end{array}$ & FEP (\%) & MET & EI & T \\
\hline \multirow{6}{*}{6} & $\mathbf{0}$ & $70.43 \mathrm{a}$ & $7.00 \mathrm{a}$ & $5.84 \mathrm{a}$ & $8.90 \mathrm{a}$ \\
& $\mathbf{2 4}$ & $69.14 \mathrm{a}$ & $6.71 \mathrm{a}$ & $5.47 \mathrm{a}$ & $9.13 \mathrm{a}$ \\
\hline \multirow{2}{*}{$\mathbf{1 2}$} & $\mathbf{4 8}$ & $69.64 \mathrm{a}$ & $7.00 \mathrm{a}$ & $5.10 \mathrm{a}$ & $9.47 \mathrm{a}$ \\
& $\mathbf{0}$ & $70.08 \mathrm{a}$ & $6.57 \mathrm{a}$ & $5.24 \mathrm{a}$ & $9.13 \mathrm{a}$ \\
& $\mathbf{2 4}$ & $69.14 \mathrm{a}$ & $6.86 \mathrm{a}$ & $5.11 \mathrm{a}$ & $9.51 \mathrm{a}$ \\
\hline Control & $\mathbf{4 8}$ & $69.29 \mathrm{a}$ & $7.00 \mathrm{a}$ & $4.96 \mathrm{a}$ & $9.59 \mathrm{a}$ \\
\hline
\end{tabular}

Final emergence percentage (FEP), Mean emergence time (MET), Emergence index (EI), Time of 50\% emergence $\left(\mathrm{T}_{50}\right)$. Mean with same letter(s) on the same column are not significantly different at $5 \%$ probability using Duncan's multiple range test.

Table 6 shows the effect of re-drying of onion seeds and the media concentration on onion seed emergence. The media concentration at $25 \%$ gave $71.08,70.67$ and $70.25 \% \mathrm{FEP}$ at 0,24 and $48 \mathrm{~h}$ DT respectively and was better than the media concentration at $12.5 \%$ which did not differ significantly $(\mathrm{P}<0.05)$ but both were significantly different from the control. The media concentration at $25 \%$ at 0 and $48 \mathrm{~h}$ DT gave the least MET (6.33 days) that differed significantly from the control ( 8.00 days) while the media concentration at $12.5 \%$ gave the highest EI (5.76) that did not differ from the control (5.60).

Table 7 shows that all the media used in this experiment were significantly different $(\mathrm{p}<0.05)$ from the control. AA gave the highest FEP at 0 DT (74.25\%). AA differed significantly from $\mathrm{NaCl}$ and water but was similar to MLE. Non re-dried onion seeds gave the highest FEP in all media used except in $\mathrm{NaCl}$. AA at $24 \mathrm{~h}$ DT gave the least MET (6.00 days) that did not differ from the other media but 
was significantly different from the control. Onion seeds soaked in water and re-drying for $48 \mathrm{~h}$ gave the least $\mathrm{EI}$ (4.25) and highest $\mathrm{T}_{50}(11.00)$ that did not differ from the other media.

Table 6: Effect of drying on media concentrations

\begin{tabular}{cccccc}
\hline $\begin{array}{c}\text { Concentration } \\
\text { (\%) }\end{array}$ & $\begin{array}{c}\text { Drying Time } \\
\text { (Hours) }\end{array}$ & FEP (\%) & MET & EI & T \\
\hline & 0 & $69.75 \mathrm{a}$ & $7.17 \mathrm{ab}$ & $5.76 \mathrm{a}$ & $8.98 \mathrm{a}$ \\
12.5 & 24 & $68.42 \mathrm{a}$ & $6.50 \mathrm{ab}$ & $5.15 \mathrm{ab}$ & $9.10 \mathrm{a}$ \\
& 48 & $69.67 \mathrm{a}$ & $7.33 \mathrm{ab}$ & $5.50 \mathrm{a}$ & $9.43 \mathrm{a}$ \\
\hline & 0 & $71.08 \mathrm{a}$ & $6.33 \mathrm{~b}$ & $5.50 \mathrm{a}$ & $8.88 \mathrm{a}$ \\
25 & 24 & $70.67 \mathrm{a}$ & $7.00 \mathrm{ab}$ & $5.63 \mathrm{a}$ & $9.18 \mathrm{a}$ \\
& 48 & $70.25 \mathrm{a}$ & $6.33 \mathrm{~b}$ & $4.82 \mathrm{ab}$ & $9.13 \mathrm{a}$ \\
\hline Control & & $60.00 \mathrm{~b}$ & $8.00 \mathrm{a}$ & $5.60 \mathrm{a}$ & $9.50 \mathrm{a}$ \\
\hline
\end{tabular}

Final emergence percentage (FEP), Mean emergence time (MET), Emergence index (EI), Time of 50\% emergence $\left(\mathrm{T}_{50}\right)$. Mean with same letter(s) on the same column are not significantly different at $5 \%$ probability using Duncan's multiple range test.

Table 7: Effect of drying on priming media

\begin{tabular}{cccccc}
\hline Media & $\begin{array}{c}\text { Drying Time } \\
\text { (Hours) }\end{array}$ & FEP (\%) & MET & EI & T50 $^{\text {(\%) }}$ \\
\hline \multirow{3}{*}{ Ascorbic acid } & $\mathbf{0}$ & $74.25 \mathrm{a}$ & $6.25 \mathrm{ab}$ & $6.10 \mathrm{a}$ & $8.95 \mathrm{~b}$ \\
& $\mathbf{2 4}$ & $72.63 \mathrm{ab}$ & $6.00 \mathrm{~b}$ & $5.24 \mathrm{ab}$ & $9.03 \mathrm{~b}$ \\
& $\mathbf{4 8}$ & $71.62 \mathrm{abc}$ & $6.75 \mathrm{ab}$ & $5.38 \mathrm{ab}$ & $9.23 \mathrm{~b}$ \\
\hline \multirow{2}{*}{ MLE } & $\mathbf{0}$ & $71.25 \mathrm{abc}$ & $7.00 \mathrm{ab}$ & $5.35 \mathrm{ab}$ & $8.88 \mathrm{~b}$ \\
& $\mathbf{2 4}$ & $69.25 \mathrm{bcde}$ & $6.50 \mathrm{ab}$ & $5.48 \mathrm{ab}$ & $8.90 \mathrm{~b}$ \\
& $\mathbf{4 8}$ & $70.00 \mathrm{bcd}$ & $6.25 \mathrm{ab}$ & $4.78 \mathrm{ab}$ & $9.15 \mathrm{~b}$ \\
\hline \multirow{2}{*}{ NaCl } & $\mathbf{0}$ & $65.75 \mathrm{e}$ & $7.00 \mathrm{ab}$ & $5.45 \mathrm{ab}$ & $8.98 \mathrm{~b}$ \\
& $\mathbf{2 4}$ & $66.75 \mathrm{de}$ & $7.75 \mathrm{ab}$ & $5.45 \mathrm{ab}$ & $9.50 \mathrm{~b}$ \\
Water & $\mathbf{4 8}$ & $68.25 \mathrm{cde}$ & $7.75 \mathrm{ab}$ & $5.33 \mathrm{ab}$ & $9.48 \mathrm{~b}$ \\
\hline Control & $\mathbf{0}$ & $69.25 \mathrm{bcde}$ & $7.00 \mathrm{ab}$ & $5.00 \mathrm{ab}$ & $9.50 \mathrm{~b}$ \\
\hline
\end{tabular}

Moringa leaf extract (MLE), Sodium chloride ( $\mathrm{NaCl}$ ), Final emergence percentage (FEP), Mean emergence time (MET), Emergence index (EI), Time of 50\% emergence $\left(\mathrm{T}_{50}\right)$. Mean with same letter(s) on the same column are not significantly different at $5 \%$ probability using Duncan's multiple range test.

\section{Discussion}

Priming of seeds had been observed to increase seed germination and emergence. The priming media increased percentage emergence and EI, reduced MET and $\mathrm{T}_{50}$. The priming with $\mathrm{NaCl}$ and water enhanced emergence compared to the control and as such reduced MGT, increased EI and caused lower $\mathrm{T}_{50}$. Nawaz et al. (2013) noted that halo-priming enhances seed germination and seedling emergence and growth in all developmental stages of the plant but the overall evidence suggests that this may not apply to some species. Selvarani and Umarani (2011) obtained improved germination and speed of seedling emergence in onion seeds primed with $\mathrm{NaCl}$ for varying durations. Priming seed with $\mathrm{NaCl}$ has resulted in early growth and better traits performance in salinity stress conditions (Khan et al., 2009; Sedghi et al., 2010; Singh et al. 2015). Sivritepe and Sivritepe (2007) observed primed seeds onion with $\mathrm{NaCl}$ for 3 days are salt tolerant to non-primed seeds. This study is in agreement with their findings as the primed onion seeds gave better germination traits than non-primed seeds irrespective of the concentration and duration of soaking. The high concentration of the salt causes osmotic retention of water such that the seeds become less accessible to water which reduces germination with increase in priming duration and subsequently affects the growth (Arif et al., 2008; Abbasdokht, 2011). Caseiro et al. (2004) found that hydro-priming was effective in improving onion seed germination while Dorna $e t$ al. (2013) observed the effect of hydro-priming on the vigour of onion seeds was not equivocal. Redrying reduced percentage emergence, increased MET and $\mathrm{T}_{50}$. In hydro priming, the lower the moisture content, the lower the percentage emergence and EI, and the higher the MET and $\mathrm{T}_{50}$. The level of moisture in seeds is one of the major factors that affect germination (Alhamdan et al. 2011). Parera and 
Cantliffe, (1992) reported that rapid re-drying can cause damage to seeds resulting in the loss of advancement gained during priming. But Huang et al. (2002) observed hydrated seeds of watermelon and onion (Dorna et al., 2013) did not lose the physiological advancement after re-drying.

The best performance in terms percentage emergence, lower MET (early emergence), EI and $\mathrm{T}_{50}$ was from AA and followed by MLE agrees with previous reports. Seed priming with AA ameliorated the adverse effects of salt stress and increased the germination traits performance in pumpkin (Rafique et al., 2011; Fazlali et al., 2013), in maize (Ahmad et al., 2015) and in broad bean (Azooz et al., 2013). Priming with AA improved drought tolerance and ensured better and uniform seedling stand and growth inwheat (Farooq et al, 2013). The MLE is a rich source of plant growth hormones- zeatin, ascorbic acid, calcium and potassium involved in several plant growth and development processes (Nouman et al., 2010). This content of AA in MLE is probably responsible for the non-significant differences in their performances as priming media for onion seeds. The use of plant growth regulators for seed priming has improved plant vigour (Jyostna and Srivastava, 1998; Afzal et al., 2002). Ifikhar (2009) had observed that priming maize seeds with MLE increased seedling emergence and caused vigorous plant development due to the presence of calcium, potassium, ascorbic acid and cytokinin hormone.

Primed seeds had higher germination percentage and emerged earlier than unprimed seeds. Rajpar et al. (2006) noted that primed seeds took fewer days to emerge. The increase in emergence percentage, reduced MET, increased EI and lower $\mathrm{T}_{50}$ may be attributed to the fact that priming induces a range of biochemical changes in the seed which involve the breaking of dormancy, hydrolysis of inhibitors, imbibition and enzyme activation required for initiating the germination process (Ajouri et al., 2004). Arifet al. (2008) observed that priming enhanced the physiological activities at seed germination.

\section{Conclusion}

This study has shown that primed onion seeds had higher germination performance as indicated by the percentage of emerged seedlings. Priming also reduced the time of seedling emergence. Redrying of primed onion seeds affected the percentage of emerged seedlings. Ascorbic acid and moringa leaf extract as priming media which ensured better performance in terms of MET, EI and $\mathrm{T}_{50}$ can be adopted as alternatives to popular priming strategies as they are effective, cheap and readily available, easily adapted and environment-friendly. Consideration should be given to the media concentration and duration of soaking in order to enhance onion percentage and time of seedling emergence and avoid damaging the seeds especially when sown under conditions not favourable for germination.

\section{Reference}

Abbasdokht, H. 2011. The effect of hydro-priming and halo-priming on germination and early growth stage of wheat (Triticum aestivum L.). Desert, 16: 61-68.

Addai, I.K., D.K. Anning, 2015. Response of onion (Allium cepa L.) to bulb size at planting and NPK 15:15:15 fertilizer application rate in the Guinea savannah agro-ecology of Ghana. J. of Agronomy, 14: 304-309.

Adebisi, M.A., S.O. Akintoye, T.O. Kehinde and M.F. Adekunle, 2011. Seed priming for improved seedling emergence and vigour of Cordia (Cordiamillennii) seed. Research J. of Seed Sci.,4: 137147.

Afzal, I., S.M.A. Basra, N. Ahmad, M.A. Cheema, E.A. Warraich and A. Khaliq, 2002. Effect of priming and growth regulator treatment on emergence seedling growth of hybrid maize. Int. J. Agric. Bio., 4: 303-306.

Ajouri, A, A. Haben and M. Becker, 2004. Seed priming enhances germination and seedling growth of barley under conditions of P and Zn deficiency. J. Plant Nutrition and Soil Science, 167:630-636.

Ahmad I, S.M.A Basra, S. Hussain, S.A. Hussain, Hafeez-ur-Rehman, A. Rehman and A. Ali, 2015. Priming with ascorbic acid, salicylic acid and hydrogen peroxide improves seedling growth of spring maize at suboptimal temperature. J. Environ \& Agric. Sci., 3:14-22.

Alhamdan, A. M., A.A. Alsadon, S.O. Khalil, M.A. Wahb-Allah, M. ElNagar, A.A. Ibrahim, 2011. Influence of storage conditions on seed quality and longevity of four vegetable crops. AmericanEurasian J. Agric. and Environ. Sci., 11(3):353-359. 
Armstrong, H. and M.B. McDonald, 1992. Effect of osmo-conditioning on water uptake and electrical conductivity in soybean seeds. Seed Sci. and Tech., 20:391-400.

Arif, M., M.T. Jan, B.K. Marwat and A.M. Khan, 2008. Seed priming improves emergence and yield of soybean. Pakistan J. of Botany, 40:1169-1177.

Azooz, M. M., A.M. Alzahrani and M.M. Youssef, 2013. The potential role of seed priming with ascorbic acid and nicotinamide and their interactions to enhance salt tolerance in broad bean (Vicia faba L.). AJCS, 7(13): 2091-2100.

Borowski, E. andS. Michałek, 2006.The effect of seed conditioning on the emergence and early growth of onion and carrot seedlings. Annales Universitatis Mariae Curie Skłodowska. Setio EEE, XVI: 119-129.

Caseiro, R., M.A. Bennett and J. Marcos-Filho, 2004. Comparison of three priming techniques for onion seed lots differing in initial seed quality. Seed Sci. \& Tech., 32, 365-375.

Di Girolamo, G. and L. Barbanti, 2012. Treatment conditions and biochemical processes influencing seed priming effectiveness. Italian J. Agr., 7:178-88.

Dorna, H., M. Jarosz, D. Szopinska, I. Smile and A. Rosinska, 2013. Germination, vigour and health of primed Allium cepa L. seeds after storage. Hortorum Cultus, 12(4):43-58.

Farooq, M., S.M.A. Basra, K. Hafeez and N.Ahmad, 2005. Thermal hardening: A new seed vigor enhancement tool in rice. J. Integrated Plant Bio., 47:187-193.

Farooq, M., S.M.A. Basra, A. Wahid, A. Khaliq and N. Kobayashi, 2009. Rice seed invigoration. In: Liehtfouse, E. (ed).Sustainable Agric. Rev., Book Series. Springer, Berlin, Germany.

Farooq, M., M. Irfan, T. Aziz, I. Ahmad and S.A. Cheema, 2013. Seed Priming with Ascorbic Acid Improves Drought Resistance of Wheat. J. Agr. and Crop Sci. 199(1):12-22.

Fazlali, R., D.E. Asli and P. Moradi, 2013. The effect of seed priming by ascorbic acid on bioactive compounds of naked seed pumpkin (Cucurbita pepovar. styriaca) under salinity stress. Intl J Farm \& Alli Sci., 2 (17):587-590.

FFD, 2011. Fertilizer Use and Management Practices for Crops in Nigeria. Chude, V. O. Olayiwola, S. O., Osho, A. O. and Dauda, C. K. (Editors). Federal Fertilizer Department, FMARD, Abuja.

FMARD, 2010. Report of the 2009. Agricultural Production Survey in Nigeria. National Programme for Agriculture and Food Security (NPAFS), Federal Ministry of Agriculture and Rural Development, Abuja. 86pp.

Huang, R., S. Sukprakarni, T. Thongket and S. Juntakool, 2002.Effect of hydro-priming and re-drying on the germination of triploid watermelon seeds. Kasetsart J. (Natural Science), 36: 219-224.

Hosseein, A.F. and M.Karsa, 2011. Effect of hydro-priming on seedling vigour in Basil (Ocimumbasilicum L.) under salinity conditions. Adv. in Environ. Bio. 5(5): 828-833.

Hussain, M., M. Farooq, S.M.A. Basra and D.J. Lee, 2013. Application of moringaallelopathy in crop sciences. In: Cheema Z., Farooq M., Wahid A. (eds) Allelopathy. Springer, Berlin, Heidelberg

Iftikhar, M.N., 2009. The Efficacy of Moringa (Moringa oleifera L.) Leaf Extract as a Seed Priming Agent in Hybrid Maize. MSc Thesis. University of Agriculture, Faisalabad, Pakistan.

Jyotsna, V. and A.K .Srivastava, 1998. Physiological basis of salt stress resistance in pigeon pea (Cajanus cajan L.). II. Pre-sowing seed soaking treatment in regulating early seedling metabolism during seed germination. Plant Physio. Biochem., 25: 89-94.

Khan, H. A., C.M. Ayub, M.A. Pervez, R.M. Bilal, M.A. Shahid and K. Ziaf, 2009. Effect of seed priming with $\mathrm{NaCl}$ on salinity tolerance of hot pepper (Capsicum annuum L.) at seedling stage. Soil Environ., 28: 81-87.

Matthews, S. and A. Powell, 2011. Towards automated single counts of radicle emergence to predict seed and seedling vigour. Seed Testing Int., 142: 44-48.

Nawaz, J., A. Jabbar, G.A. Nadeem, M. Sajid, M.S ubtain, and I. Shabbir, 2013. Seed priming techniques. Intl. J. Agric. Crop Sci., 6(20), 1373-1381.

Nouman, W., M.T. Siddiqui and S.M.A. Basra, 2012. Moringa oleifera leaf extract: An innovative priming tool for rangeland grasses. Turk. J. Agric. For., 36:65-75.

Parera, C. A. and D.J. Cantliffe, 1992. Enhanced emergence and seedling vigor in shrunken-2 sweet corn via seed disinfection and solid matrix priming. J. of American S. of Hort. Sci., 117:400-403.

Rafique, N., S.H. Raza, M. Qasim and N. Iqbal, 2011.Pre-sowing application of ascorbic acid and salicylic acid to seed of pumpkin and seedling response to salt. Pak. J. Bot., 43(6): 2677-2682. 
Rajpar, I., Y.M. Khanif and A.A. Memon, 2006. Effect of seed priming on growth and yield of wheat (Triticum aestivum L.) under non-saline conditions. Int. J. Agric. Res., 1:259-264.

Ratikanta, K.M., 2011. Seed priming: an efficient farmers' technology to improve seedling vigour, seedling establishment and crop productivity. Intl. J. Bio-res. Stress Manag., 2, 297.

Saranya N, J. Renugadevi, K. Raja, V. Rajashree, and G. Hemalatha, 2017. Seed priming studies for vigour enhancement in onions Co Onion (5). J. Pharmacognosy and Phytochem., 6(3): 77-82.

Selvarani, K. and R. Umarani, 2011. Evaluation of seed priming methods to improve seed vigor of onion (Allium cepa cv. aggregatum) and carrot (Daucuscarota). J. Agric. Technol., 7: 857-867.

Singh, H., R.K. Jassal, J.S. Kang, S.S. Sandhu, H. Kang, and K. Grewal, 2015.Seed priming techniques in field crops - A review. Agri. Review, 36 (4): 251-264.

Sivritepe, H.Ö. and N. Sivritepe, 2007.NaCl Priming Affects Salt Tolerance of Onion (Allium cepaL.) Seedlings. Acta Horticulturae, 729:157-161.

Tadimalla, R.T., 2017.31 Surprising Benefits of Onions (Pyaz) for Skin, Hair and Health. www.stylecraze.com/articles/amazing-health-benefits-of-onionsHubPagesInc Copyright 2017.

Wu, L., D. Yao and M. Li, 2017. Effects of solid matrix priming with Trichoderma harzianum on seed germination, seedling emergence and photosynthetic capacity of eggplant. African J. of Biotech., 16(14): 699-703. 